\title{
Research on College English Writing Teaching Mode Based on Corpus
}

\author{
Meijing LI \\ Foreign Language Department of Jilin Business and Technology College \\ Changchun City, China \\ Email:liuliucream@163.com
}

\begin{abstract}
This study takes the two freshman classes in nonEnglish major respectively as the experimental class and that control class. During the one-year experiment, two kinds of teaching mode: college English writing teaching mode based on the corpus and traditional mode of college English writing teaching, are adopted respectively to conduct English writing teaching in experimental class and control class. The empirical study uses SPSS19.0 to do statistical analysis for experimental data and the analysis results show that the writing level of students in experimental class is significantly higher than that in control class. The results show that college English writing teaching model based on the corpus can effectively improve the students' writing level, and the improvement of students' writing level will help to improve students' comprehensive language application ability.
\end{abstract}

Keywords-Corpus; College English writing teaching mode; Comprehensive language application ability

\section{INTRODUCTION}

English writing ability, as one of the five core abilities of college students' comprehensive language application: listening, speaking, reading and writing, is the hot spot of college English teaching and research. College English teachers and researchers in our country have launched a variety of research and practice on how to improve the students' English writing level.

However, in the context of teaching effect, students' writing ability also fails to achieve the expected goals. With the emergence of computer and network technology, it enables the teaching means and methods in college to experience great changes, which also has a huge impact on the traditional teaching methods of college English writing teaching which take the textbooks and homework as the main teaching media and teachers' classroom teaching as the main method, sparking the thought of the teaching patterns in public. ${ }^{[1]}$

Education department issued College English Curriculum Teaching Requirements (2007 version) (hereinafter referred to as Teaching requirement) has a clear requirement for the reform of the teaching mode, namely "Higher schools should make full use of modern information and technology, give priority to English teaching model with computer and improve traditional teaching model. The new teaching pattern should be based on the modern information and technology, especially taking network technology as the support, which can make English teaching and learning be less limited by objective resources in a definite degree and develop individually and autonomously.

The appearance of corpus linguistics provides a new perspective for teaching model reform based on computer and network technology, which has a unique advantage in teaching resources, evaluation and feedback and students' autonomous learning. The emergence of corpus not only marks the technological progress of linguistics research, but also marks a major change in language research thought. It represents a new linguistic thinking and a new career. This study, under the guidance of teaching requirements, independently designs and creates the college English writing corpus, ${ }^{[2]}$ and on this basis, builds a corpus-based college English writing teaching platform system using computer and network technology and explore the application of corpus in college English writing teaching mode reform.

\section{CONSTRUCtion OF COLlEGE ENGLiSH Writing TEACHING MODE BASED ON CORPUS}

Corpus refers to a large electronic library with a certain capacity constructed by collecting naturally occurring continuous language text or pieces of discourse according to certain principles of linguistics using random sampling method. The application of corpus linguistics research and technology education in foreign language teaching is now a remarkable new areas in the development of applied linguistics, which has a unique advantage. On the one hand, a large amount of real and rich language materials can reflect the livliness of language use and have a great explanatory power in the use of language paradigm. On the other hand, the research methods, such as word index line, word frequency table, keyword table, etc., provide technical support for the inquiry-based learning, which is conducive to the implementation of autonomous learning.

The application of corpus in the writing teaching abroad mainly focuses on the following three aspects:

1. The teaching resources providing. For instance, the Academic vocabulary corpus developed by Coxhead is used 
to design vocabulary and reading writing textbooks for English for Academic Purpose.

2. Direct meet with teaching. For example, the Data Driven Learning proposed by Johns thinks corpus in foreign language teaching for middle school students can be based on corpus of authentic language data, make an observation, description and conclusion of the language use with the help of corpus check cable technology. ${ }^{[3]}$

3. The teaching result analysis. Corder believed it not the most effective approach to simply present students the correct form of the language but sometimes get in the way to explore and learn the other ways. It is significant to let learners try the method of self-discovery and errors analysis to find the right form of language. Learners can analyze, conclude and find the errors in learning language through corpus inspection technology, which will be more conducive to the learner's study.

At home, the research on the application of corpus linguistics in the study of teaching arose in the early 1980s, which is marked by Huang Renjie and Yang Huizhong's JDEST in 1982. But until the 1990s, domestic scholars began to put forward the application of corpus to the foreign language teaching practice, such as Xie Yingguang (1996), Li Wenzhong (1999). Currently, researches on the application of corpus in college English writing teaching mainly set in analytic research on the application of corpus technology in some language phenomena in Chinese students' English writing, such as Li Jingquan, Cai Jinting(2001), Wen Qiufang(2003) and Zhou Chuan (2010). Unfortunately, researches on the teaching model of college English writing are limited. This study attempts to make a combination of corpus and the reform of college English writing teaching mode for the purpose of achieving a successful reforming mode in college English writing teaching practice.

The corpus in this paper collects about more than 1500 compositions with all kinds of style and theme, which can be increased at any time according to the teaching requirement. Teachers and students can use corpus retrieval technology to observe, describe, induce and explore the language writing rules according to their own needs. Students' compositions are included into corpus in the form of electronic document, and teacher carries on analysis and evaluation by corpus technology.

The whole process of students' improvement in writing will be automatically generated as student profiles for reference of teachers and students themselves. The model can be summarized as " $3+1 "$ mode, namely: corpus platform, communication platform between teachers and students and students exchange platforms, which have made up of college English writing teaching platforms based on corpus. Teachers should make full use of the advantages of modern information and technology combining with the traditional classroom teaching so as to improve students' college English writing. It is specifically listed and analyzed as follows:

\section{A. Students-corpus platform-teachers}

the process is the core of the whole teaching mode. Students log in college English writing teaching platform based on corpus with student ID and real name as the user name. After completing writing tasks assigned by the teacher, the composition is sent to a corpus platform in the form of electronic document. Teachers give their evaluation to students' compositions in use of the college English test analyzer. Teachers use the "standard for speech errors classification" proposed by Chinese Learner Corpus (Gui Shichun, Yang Huizhong, 2003:4-8) to annotate the speech errors in students' compositions, and analyze the speech errors by using corpus technology. Combined with the preliminary evaluation, a complete evaluation report of compositions is formed.

\section{B. Students-exchange platform between teachers and students-teachers}

Teachers and students can communicate and discuss related issues on composition writing through the network platform. The platform is divided into two channels: public and private. The content of the public channel is shared to all users to participate in discussion. Private channel is only available to the permitted users.

\section{Students-student exchange platform-students}

Students are required to form study groups, in addition to the face to face communication between each other, they still can discuss over their compositions through the network communication platform. At the same time, according to the overall discussion, excellent compositions are ranked at the top of corpus platform. ${ }^{[4]}$ Teachers play a role of supervision in the process to prevent the excessive and inappropriate behavior, but don't participate in the discussion.

\section{Students-classroom teaching-teachers}

Teachers, in use of the teaching platform, collect related information and choose some representative problems for discussion in classroom teaching so as to improve the classroom teaching effect.

\section{EXPERIMENTAL RESEARCH}

\section{A. Research hypothesis}

- College English writing teaching model based on the corpus can effectively improve students' English writing level.

- Students' English comprehensive application ability increases with the improvement of English writing.

\section{B. Research subject}

According to entrance examination scores of freshmen, 94 non-English major students in 2013 are selected as the research object. There are 46 students in experimental class with corpus-based English writing teaching mode. There are 48 people in control class with traditional teaching mode. 
Two classes' language comprehensive application ability and writing level have no obvious difference, so, the experiment can be carried out.

\section{Research procedure}

- Before experiment: non-English major students in 2013 attend the university entrance exam of English, according to test results, two classes with insignificant difference in the number of students and background are selected as experimental classes and control class.

- During the experiment: Experiment class students take college English writing teaching mode based on corpus, and control class adopts the traditional teaching method. Teachers assign a composition every two weeks and students must complete it in 30 minutes after class. Students in experimental class include their compositions into corpus in the form of electronic document and analyze and evaluate the compositions through corpus technology. Students' compositions in control class are reviewed and corrected by the teacher. To reduce the error resulting from human factors, teacher in experimental class and control class is the same person.

- After the experiment: Collect experimental class and control class's result scores after test on June 6, 2014 and compare it with the scores in college English entrance examination before September 2013, at the same time undertake student questionnaire.

\section{RESUlt AND ANALYSIS}

Through the one-day teaching experiment, the pretest and posttest scores of students in the experimental class and control class are analyzed with SPSS 19.0 by conducting independent sample t-test, so as to test whether the related variables of pretest and posttest scores of students respectively in the experimental class and control class have any significance difference and conduct discussion and analysis combining with questionnaire survey results. Analysis shows that college English writing teaching model based on the corpus has significantly improved the students' college English writing level.

The following tables show the independent sample $t$ test of pretest and posttest scores of students respectively in the experimental class and control class.

TABLE I. INDEPENDENT SAMPLE T TEST OF PRETEST

\begin{tabular}{|l|l|l|l|l|l|}
\hline \multicolumn{6}{|c|}{ Group Statistics } \\
\hline & Experiment class & $\mathrm{N}$ & Mean & Std. Deviation & Std. Error Mean \\
\hline Score & A & 46 & 8.5217 & 1.48682 & .21922 \\
\hline & B & 46 & 10.5543 & 1.76455 & .26017 \\
\hline
\end{tabular}

TABLE II. POSTTEST SCORES OF STUDENTS RESPECTIVELY IN THE EXPERIMENTAL CLASS AND CONTROL CLASS

\begin{tabular}{|c|c|c|c|c|c|c|c|c|c|c|}
\hline \multicolumn{11}{|c|}{ Independent Samples Test } \\
\hline & & \multicolumn{2}{|c|}{$\begin{array}{c}\text { Levene's } \\
\text { Test for } \\
\text { Equality of } \\
\text { Variances } \\
\end{array}$} & \multicolumn{7}{|c|}{ t-test for Equality of Means } \\
\hline & & \multirow[t]{2}{*}{$\mathrm{F}$} & \multirow[t]{2}{*}{ Sig. } & \multirow[t]{2}{*}{$\mathrm{t}$} & \multirow[t]{2}{*}{$\mathrm{df}$} & \multirow[t]{2}{*}{$\begin{array}{l}\text { Sig. } \\
(2- \\
\text { tailed }\end{array}$} & \multirow[t]{2}{*}{\begin{tabular}{|c} 
Mean \\
Differ \\
ence \\
\end{tabular}} & \multirow[t]{2}{*}{$\begin{array}{c}\text { Std. Error } \\
\text { Differen- } \\
\text { ce }\end{array}$} & \multicolumn{2}{|c|}{$\begin{array}{l}95 \% \text { Confidence } \\
\text { Interval of the } \\
\text { Difference }\end{array}$} \\
\hline & & & & & & & & & Lower & Upper \\
\hline Score & $\begin{array}{c}\text { Equal } \\
\text { variances } \\
\text { assumed }\end{array}$ & 3.650 & .059 & -5.975 & 90 & .000 & $\begin{array}{c}- \\
2.0326 \\
1\end{array}$ & .34021 & -2.70850 & $\begin{array}{c}- \\
1.35672\end{array}$ \\
\hline & $\begin{array}{c}\text { Equal } \\
\text { variances } \\
\text { not } \\
\text { assumed }\end{array}$ & & & -5.975 & $\begin{array}{c}87.48 \\
3\end{array}$ & .000 & $\begin{array}{c}- \\
2.0326 \\
1\end{array}$ & .34021 & -2.70877 & $\begin{array}{c}- \\
1.35645\end{array}$ \\
\hline
\end{tabular}

Through college English writing teaching model based on the corpus, the composition average score of students in experimental class is 10.55 , while the composition average score of students in control class is 9.58, which are respectively increase 2.03 and 0.95 . It shows that the overall writing skills of students in experimental class is increased higher than that in control class.

After the experiment, an open questionnaire survey on the students in experimental class is carried out. The questionnaire results are mainly concentrated in the following two aspects:

\section{A. A large number of reliable and detailed writing corpus}

most of the students think corpus technology retrieval is of great help to their writing level. Students can analyze, induce and summarize language rules by themselves so as to be able to cast off the yoke of the textbook and class and really carry out autonomous learning. To compare with the traditional classroom teaching which can only provide one or two model compositions, students are more willing to find related corpus which are suitable for their own learning according to individual characteristics analysis. ${ }^{[5]}$

\section{B. Efficient and complete file system}

college English writing teaching mode based on the corpus can provide students with their students their individual profiles and evaluation report. Students think that it is a process to understand their own learning, which can help them to have a comprehensive grasp of learning situation and is very helpful to improve the level of writing.

\section{CONCLUSION}

This research confirms the effectiveness of college English writing teaching model based on corpus by the comparative experiment. The study finds that college English writing teaching mode based on corpus, compared with traditional model, can more effectively improve the students' English writing level, and the improvement of English writing helps to improve English comprehensive application ability. But the teaching pattern also has certain limitation, for example, it is highly dependent on hardware, such as computer and network. The lack of these devices 
will affect the English writing teaching and limit its popularization and application scope.

At the same time, the study also finds that the teachers' feedback will affect the enthusiasm of students learning and writing, in addition, if students' compositions are widely concerned and placed at the top of platform, it will greatly stimulate the top student's writing enthusiasm, all these problems still need to explore in the future research. In conclusion, college English writing teaching model based on corpus is only an early attempt to analyze the application of corpus in foreign language education. With the development of corpus linguistics, we think that the application of corpus in foreign language education and research will be increasingly widespread.

\section{REFERENCE}

[1] Swain, M. Three Functions of Output in Second Language learning[C] G. Cook\& B .Seidhofer. Principles\&Practice Applied Linguistics. Oxford:Oxford University Press, 1995

[2] Ge Lingling, Li Guangwei, Li Chaohui. College English teaching platform construction and its teaching mode based on the corpus[J]Foreign Language World.2011 ( 5)

[3] Cai Jigang. College English CET 4 and CET 6 writing requirements and grading standard for Chinese students[J] The Journal of Specialised Translation,2005( 5)

[4] Luo Yi, Cai Huiping, Wangjin. The application of experiential teaching theory in English writing teaching[J]. 2011(1)

[5] Department of Higher Education. College English Curriculum Requirements [Z] Shang Hai: Shanghai Foreign Language Education Press, 2007 